Media Informatika, Vol. 3 No. 1, Juni 2005, 47-59

ISSN: 0854-4743

\title{
SISTEM PENGIDENTIFIKASI OTOMATIS POKOK KALIMAT SUATU PARAGRAF DALAM DOKUMEN EKSPOSITORI DENGAN MODEL RUANG VEKTOR
}

\author{
Muhammad Erwin Ashari Haryono \\ Laboratorium Pemrograman dan Informatika Teori, \\ Jurusan Teknik Informatika, Fakultas Teknologi Industri, Universitas Islam Indonesia \\ Jl. Kaliurang Km. 14 Yogyakarta 55501 \\ Telp. (0274) 895287 ext. 122, Faks. (0274) 895007 ext. 148 \\ E-mail:meah@fti.uii.ac.id
}

\begin{abstract}
ABSTRAK
Suatu dokumen biasanya terdiri dari bermacam-macam topik, berbeda dengan abstraksi yang ringkas dan padat informasi. Identifikasi dan isolasi pokok kalimat dengan membagi-bagi dokumen, yang disebut segmentasi teks, merupakan hal yang penting dalam pemrosesan bahasa alami, termasuk mesin penterjemah dan information retrievel. Dalam information retrievel, pengguna sering kali hanya tertarik pada bagian tertentu dari dokumen yang diambil, bukan pada keseluruhan dokumen itu. Untuk memenuhi kebutuhan tersebut dokumen harus disegmentasi ke dalam bagian-bagian yang koheren atau berkaitan. Segmentasi dokumen ke dalam blok-blok teks dengan pokok kalimat yang sama dapat membantu search engine untuk memilih dan mengambil suatu segmen yang seusai dengan query yang diajukan pengguna. Segmentasi yang secara nyata dapat dilihat adalah adanya pembagian dokumen dalam paragraf-paragraf. Penelitian yang dilakukan bertujuan memberikan kemudahan bagi pengguna dokumen ekspositori untuk memahami dokumen yang akan digunakan. Hasil yang diperoleh setelah dilakukan pengujian terdahap sistem adalah sebesar 50\% dinilai dari kesesuaian penentuan pokok kalimat yang ditentukan secara manual dan oleh sistem.
\end{abstract}

Kata Kunci: information retrievel, segmentasi teks, vector space model, tokenisasi

\section{PENDAHULUAN}

Penelitian ini adalah studi kasus khusus dari bidang pengolahan bahasa alami yang memfokuskan pada pencarian pokok kalimat dari suatu paragraf. Penentuan pokok kalimat secara alami oleh manusia dapat sangat mudah untuk dilakukan dikarenakan kemampuan manusia untuk dapat merangkum dan menentukan kata-kata mana yang bersesuaian yang dapat membentuk suatu kesatuan cerita walaupun terkadang manusia pun akan menemukan kesulitan juga dalam penentuan itu. Dalam bidang komputer terutama Informatika, hal ini dibahas lebih lanjut dalam studi kepustakaan antara kemampuan tata bahasa linguistik, pembentukan parsing, aturan, dan pemrograman yang cukup efisien. Penentuan pokok kalimat tersebut dilakukan dengan membagi (segmentation) kalimat dalam suatu alinea paragraf yang koheren dan berkaitan. Segmentasi 
paragraf ke dalam blok-blok teks dengan membantu mesin pencari untuk melakukan pembagian atau clustering terhadap pokok kalimat yang sama dalam beberapa alinea paragraf nantinya.

\subsection{Wacana Paragraf}

Dalam pendidikan formal diajarkan bahwa paragraf dituliskan sebagai suatu kesatuan yang utuh, memiliki kalimat pokok pikiran (pokok pembicaraan atau topik) dan dilengkapi dengan kalimat penjelasannya. Dalam kenyataannya, kondisi ini sering tidak terpenuhi. Penandaan paragraf tidak selalu digunakan dalam tampilan fisik untuk membantu dalam pembacaan. Struktur dari dokumen ekspository dapat dikarakterisasi sebagai rangkaian pokok kalimat atau pokok pembicaraan yang berhubungan dengan topik utamanya. Struktur pokok kalimat seringkali ditandai dengan judul dan subjudul yang membagi dokumen ke dalam segmen yang berkaitan. Tetapi banyak juga dokumen yang terdiri dari rangkaian paragraf yang panjang dengan batas-batas struktural yang tidak jelas, ataupun yang terdiri dari rangkaian paragraf yang masih membicarakan pokok kalimat yang sama.

Salton dkk (1993) telah melakukan penelitian menggunakan teks dari buku ensiklopedia dan menyatakan bahwa query terhadap seksi dan paragraf memberikan hasil yang lebih baik dibandingkan dengan query terhadap keseluruhan dokumen (Hearst, 1993).. Morris dan Hist (1991) mempelopori penelitian dalam komputasi struktur tulisan berdasarkan hubungan keterkaitan secara leksikal. Dengan menggunakan thesaurus yang lengkap (Roget's Fourth Edition), Morris telah mengembangkan suatu algoritma yang dapat menenemukan rantai dari term-term yang berhubungan. Tetapi algoritma tersebut bertujuan untuk menemukan struktur attentional/intentional, berbeda dari yang dilakukan Hears dalam Texttilling, yang menggunakan hubungan keterkaitan secara leksikal untuk membagi-bagi dokumen ke dalam segmen-segmen yang mencerminkan struktur pokok kalimatnya.

\subsection{Model Ruang Vektor}

Model ruang vektor dilakukan untuk melihat nilai kemiripan suatu dokumen terhadap suatu query. Pembobotan secara otomatis biasanya berdasarkan jumlah kemunculan suatu istilah dalam sebuah dokumen (term frequency/tf) dan jumlah kemunculannya dalam koleksi dokumen (inverse document frequency/idf). Bobot suatu istilah semakin besar jika istilah tersebut sering muncul dalam suatu dokumen dan semakin kecil jika istilah tersebut muncul dalam banyak dokumen (Grossman, 1998).

Saat mesin menerima query, mesin akan membangun sebuah vektor $Q$ $\left(\mathrm{w}_{\mathrm{q} 1}, \mathrm{w}_{\mathrm{q} 2}, \ldots \mathrm{w}_{\mathrm{qt}}\right)$ berdasarkan istilah-istilah pada query dan sebuah vektor $\mathrm{D}$ $\left(\mathrm{d}_{\mathrm{i} 1}, \mathrm{~d}_{\mathrm{i} 2}, \ldots \mathrm{d}_{\mathrm{it}}\right)$ berukuran $\mathrm{t}$ untuk setiap dokumen. Pada umumnya SC dihitung dengan rumus Cosine Measure seperti persamaan 1 (Grossman, 1998). Selain persamaan 1 juga terdapat berbagai persamaan yang dapat dilakukan, persamaan tersebut adalah pers 6 , pers 7 dan pers 8 . 
dimana:

$$
S C\left(b_{1}, b_{2}\right)=\frac{\sum_{t=1}^{n} w_{t, b 1} w_{t, b 2}}{\sqrt{\sum_{t=1}^{n} w_{t, b 1}^{2} \sum_{j=1}^{n} w_{t, b 2}^{2}}}
$$

$\mathrm{t}=$ term dalam kalimat

$\mathrm{w}_{\mathrm{t}, \mathrm{b} 1}=$ bobot yang diberikan pada term $\mathrm{t}$ dalam blok $\mathrm{b}_{1}$

$\mathrm{w}_{\mathrm{t}, \mathrm{b} 2}=$ bobot yang diberikan pada term $\mathrm{t}$ dalam blok $\mathrm{b}_{2}$

Terdapat beberapa macam perhitungan Similarity Coeficient yaitu menggunakan rumus cosine measure dan normalized cosine measure.

$$
\begin{gathered}
n w_{q j}=\frac{\text { freq }_{q j}}{\max _{k} \text { freq }_{q k}}{ }^{*}{ }^{*} \text { iddf } f_{j} \\
n d_{i j}=n t f_{i j}{ }^{*} n i d f_{j} \\
n t f_{i j}=\frac{t f_{i j}}{\max k t f_{i k}} \\
n i d f_{j}=\frac{\log (d)-\log \left(d f_{j}\right)}{\log (d)}=1-\frac{\log \left(d f_{j}\right)}{\log (d)}
\end{gathered}
$$

\section{METODOLOGI PERANCANGAN}

Model yang akan dikembangkan dalam penentuan topik dalam suatu paragraf dalam penelitian dapat dilihat dalam Gambar 1.

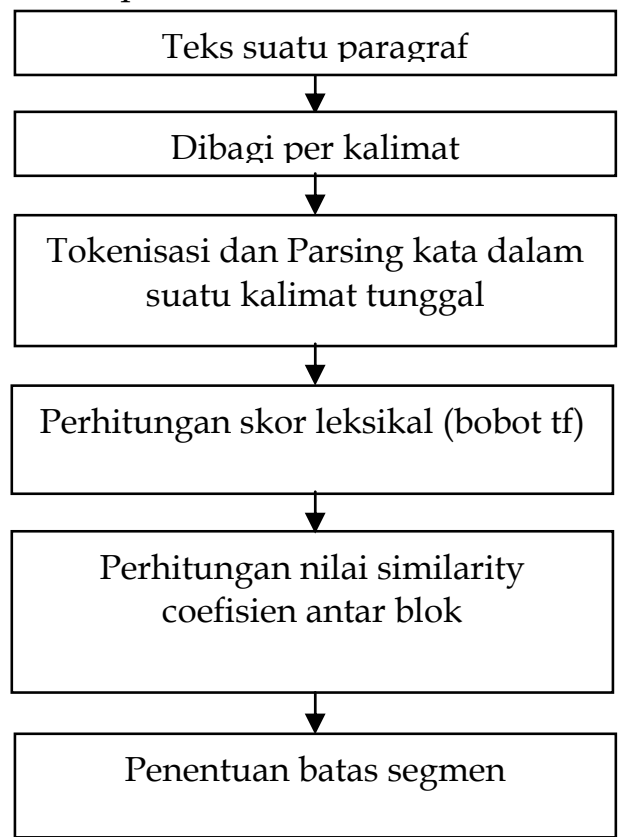

Gambar 1. Langkah-langkah penentuan topik suatu paragraf 
Kesulitan dalam penentuan kalimat adalah tanda titik yang ada. Dalam penelitian ini kajian permasalahan dibatasi pada tidak diacuhkannya format penanda titik. Titik terkadang tidak menentukan akhir suatu kalimat. Titik dapat digunakan untuk identifikasi akhir jalan, gelar dan lainnya. Gambar 1 adalah alur proses dari pencarian pokok kalimat secara otomatis dalam suatu paragraf. Langkah pertama adalah dilakukannya penelusuran (scanning) terhadap paragraf untuk memilah paragraf tersebut perkalimatnya.

Contoh:

"Hugo, a grassland boy, is sent as grassland chief Lucia envoy to zexen capital. Simultuneously, a battle between Zexen and Grassland begin, Hugo the grassland boy are seized by the zexen knights. Hugo can escape from zexen, now Hugo back to grassland".

sehingga pembagian per kalimat menjadi:

Kalimat pertama:

"Hugo, a grassland boy, is sent as grassland chief Lucia envoy to zexen capital".

Kalimat kedua:

"Simultuneously, a battle between Zexen and Grassland begin, Hugo the grassland boy are seized by the zexen knights".

Kalimat ketiga:

"Hugo can escape from zexen, now Hugo back to grassland".

Setelah dilakukan pembagian perkalimat, kemudian dilakukan proses parsing dan pembuatan indeks masing-masing kata beserta letak kalimat keberapa pada samping bobot. Bobot dihitung berdasarkan besar frekuensi yang muncul dalam setiap kalimat dan seberapa seringnya kata tersebut muncul secara keseluruhan pada satu paragraf tersebut. Semakin banyak kata tersebut muncul pada setiap kalimat, maka nilai bobot kata tersebut akan besar, tetapi bila kata tersebut muncul pada beberapa kalimat maka bobot kata tersebut akan berkurang (inverse document frequency). Sebelum di indeks maka ada kata-kata yang akan dibuang dari kalimat tersebut (stoplist), pembuangan dilakukan karena sering munculnya kata tersebut sehingga diasumsikan sebagai kata yang umum dan tidak berguna (seperti atau, dan, dia, saya, oleh dan lain-lain).

Proses selanjutnya adalah perhitungan nilai Similarity Coeficient (SC). Banyak terdapat model untuk mencari nilai kemiripan tersebut (selain model pada rumus 1), model lain diantaranya adalah:

\section{Model dot product}

$$
\mathrm{SC}(\mathrm{Q}, \mathrm{Di})=(\mathrm{Di})(\mathrm{Q})
$$

\section{Model Dice}




$$
\mathrm{SC}(\mathrm{Q}, \mathrm{Di})=2(\mathrm{Di})(\mathrm{Q}) /(\mathrm{Di} 2)(\mathrm{Q} 2)
$$

\section{Model Jaccard}

$$
\mathrm{SC}(\mathrm{Q}, \mathrm{Di})=(\mathrm{DiQ}) /((\mathrm{Di}) 2+\mathrm{Q} 2-|\mathrm{Di}||\mathrm{Q}|)
$$

Selanjutnya setiap kata setiap kalimat tersebut dimasukkan ke dalam blok token tiap posisinya. Beserta bobot frekuensinya. Contoh pembentukan blok dapat dilihat pada Tabel 1.

Tabel 1. Contoh frekuensi term dalam blok

\begin{tabular}{|l|c|c|c|}
\hline \multirow{2}{*}{ Token } & \multicolumn{3}{|c|}{ Frekuensi } \\
\cline { 2 - 4 } & Blok 1 & Blok 2 & Blok 3 \\
\hline Hugo & 1 & 1 & 2 \\
\hline Grassland & 2 & 2 & 1 \\
\hline Boy & 1 & 1 & 0 \\
\hline Chief & 1 & 1 & 0 \\
\hline Lucia & 1 & 0 & 0 \\
\hline Envoy & 1 & 0 & 0 \\
\hline Zexen & 1 & 2 & 1 \\
\hline Capital & 1 & 0 & 0 \\
\hline Simultuneously & 0 & 1 & 0 \\
\hline Battle & 0 & 1 & 0 \\
\hline Begin & 0 & 1 & 0 \\
\hline Seized & 0 & 1 & 0 \\
\hline Knights & 0 & 1 & 1 \\
\hline Escape & 0 & 0 & 1 \\
\hline Back & 0 & 0 & \\
\hline
\end{tabular}

Dalam tabel tersebut menyatakan bahwa kata/ token "Hugo" terdapat pada kalimat ke 1, ke 2 dan ke 3 dengan frekuensi 1, 1 dan 2, begitu juga seterusnya. Kemudian perhitungan kemiripan antar kalimat pada Blok 1, Blok 2 dan Blok 3 adalah sebagai berikut:

$$
\begin{aligned}
\cos (B 1, B 2)= & \frac{(1)(1)+(2)(2)+(1)(1)+(1)(2)}{\sqrt{\left(1^{2}+2^{2}+1^{2}+1^{2}\right)\left(1^{2}+2^{2}+1^{2}+2^{2}\right)}} \\
& =\frac{8}{\sqrt{(7)(10)}} \\
& =0.9562
\end{aligned}
$$

Dengan cara yang sama diperoleh:

$\cos (B 1, B 3)=0.8333$

$\cos (B 2, B 3)=0.8165$

Perhitungan nilai similarity coefficient tiap kalimat adalah: 


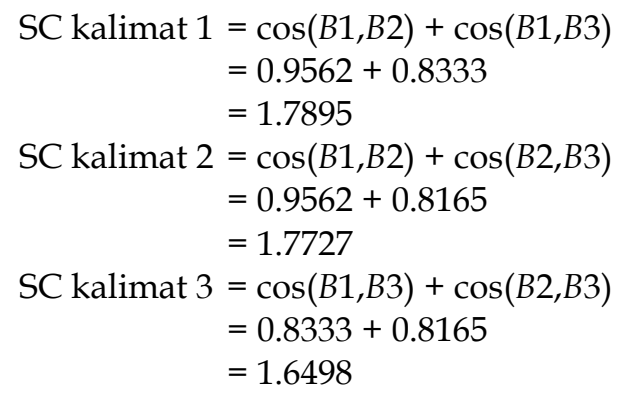

Dari perhitungan nilai similarity coefficient diatas maka diperoleh kalimat pertama sebagai pokok kalimat dari dokumen dengan nilai similarity coefficient 1.7895 .

Dalam penelitian sebelumnya Tannen (1989), Halliday \& Hasan (1976), Walker (1991), dan Hearst (1993) menemukan bahwa perulangan suatu term atau kata dalam suatu kalimat dalam suatu paragraf menunjukkan indikasi sangat penting dalam menentukan struktur pokok kalimat paragraf. Blok-blok dibangun berdasar kalimat-kalimat yang ada di dalam paragraf yang akan dicari topik nya. Identifikasi keterkaitan secara leksikal adalah dengan membandingkan pasangan blok-blok teks berurutan, kemudian dihitung besar kemiripannya antara dua blok teks. Semakin besar kemiripannya maka topik cerita antar kalimat saling berkelanjutan.

\section{IMPLEMENTASI}

Penelitian dilakukan terhadap sejumlah teks paragraf yang didapat dari surat kabar, buku dan majalah. 32 Sampel cerita diambil, dimana tiap paragraf diberikan judgment intisarinya secara manual terlebih dahulu oleh penulis dan rekan penulis. Implementasi dilakukan dengan mencocokkan hasil pokok kalimat otomatis oleh sistem dan hasil pokok kalimat yang telah ditentukan oleh penulis untuk masing-masing paragrafnya.

\section{Contoh:}

The hottest day of the summer so far was drawing to a close and a drowsy silence lay over the large, square houses of Privet Drive. Cars that were usually gleaming stood dusty in their drives and lawns that were once emerald green lay parched and yellowing for the use of hosepipes had been banned due to drought. Deprived of their usual carwashing and lawn-mowing pursuits, the inhabitants of Privet Drive had retreated into the shade of their cool houses, windows thrown wide in the hope of tempting in a nonexistent breeze. The only person left outdoors was a teenage boy who was lying flat on his back in a flowerbed outside number four. He was a skinny, black-haired, bespectacled boy who had the pinched, slightly unhealthy look of someone who has grown a lot in a short space of time. His jeans were torn and dirty, his T-shirt baggy and faded, and the soles of his trainers were peeling away from the uppers. Harry Potter's appearance did not endear him to the neighbours, who were the sort of people who thought scruffi-ness ought to be punishable by law, but as he had hidden himself behind a large hydrangea bush this evening he was quite 
invisible to passers-by. In fact, the only way he would be spotted was if his Uncle Vernon or Aunt Petunia stuck their heads out of the living-room window and looked straight down into the flowerbed below.

Berdasarkan contoh kasus maka setelah dilakukan pengujian didapatkan hasil pengujian seperti terlihat pada Gambar 2, 3, 4, 5, 6, 7 dan 8. Pada bagian process output utama menampilkan hasil keluaran sistem yang utama yaitu kalimat pertama dianggap sebagai pokok kalimat paragraf. Dalam paragraf tersebut terdapat 8 kalimat, 219 kata, 571 daftar kata yang masuk dalam skip list, 98 kata yang dianggap valid dan nilai similarity coefficient tertinggi adalah 0,7396602 (kasus) dapat dilihat seperti pada Gambar 3.

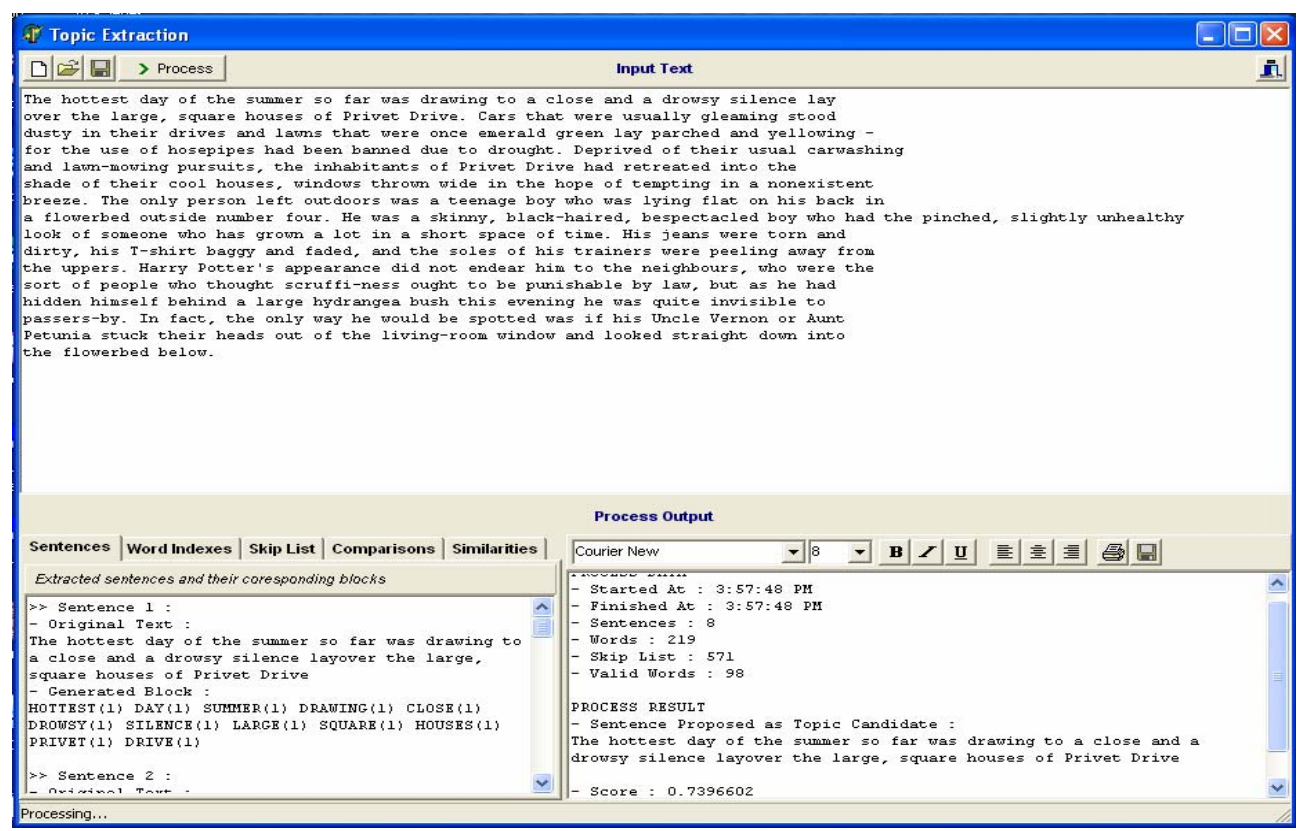

Gambar 2. Antarmuka sistem (kasus)

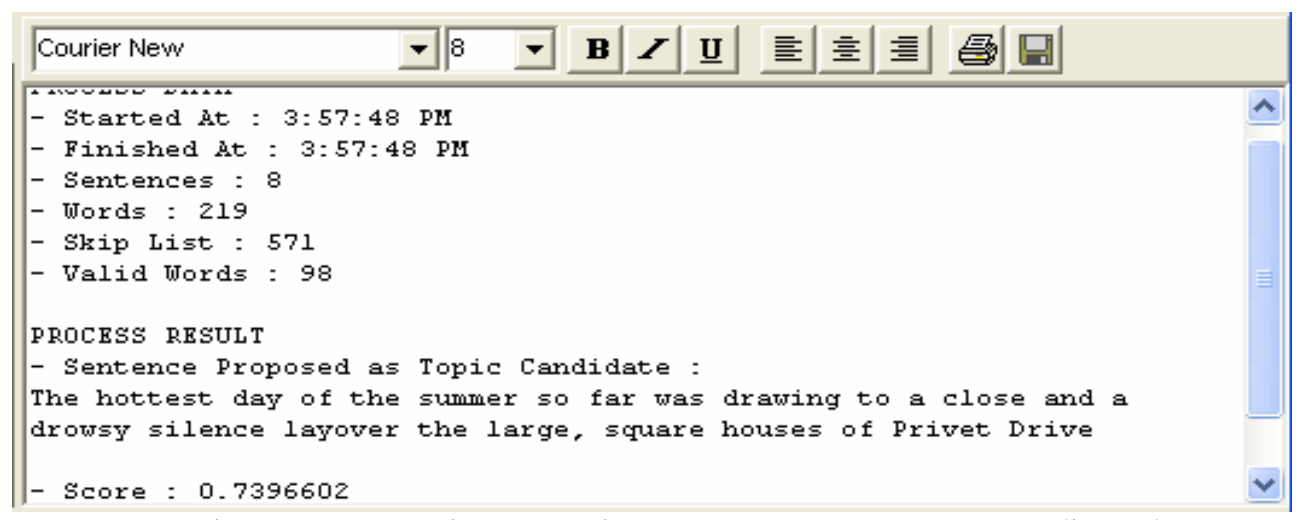

Gambar 3. Antarmuka sistem bagian process output utama (kasus) 
Pada bagian process output terperinci pada tombol sentences ini menampilkan kalimat-kalimat yang terdapat pada dokumen (kasus) yang telah dipisah perkalimat beserta kata-kata yang dianggap valid dan jumlah kemunculannya didalam kalimat tersebut, dapat dilihat seperti pada Gambar 4.

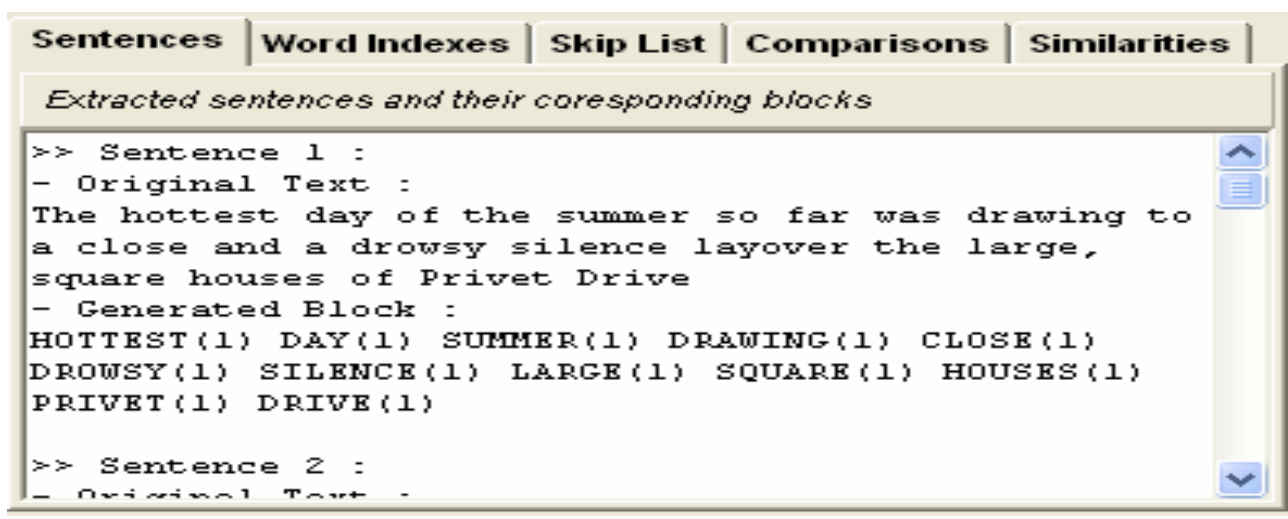

Gambar 4. Antarmuka sistem bagian process output terperinci pada tombol sentences (kasus)

Pada bagian process output terperinci pada tombol word indexes ini menampilkan daftar kata-kata yang dianggap valid beserta jumlah kemunculannya dalam keseluruhan dokumen (kasus), dapat dilihat seperti pada Gambar 5.

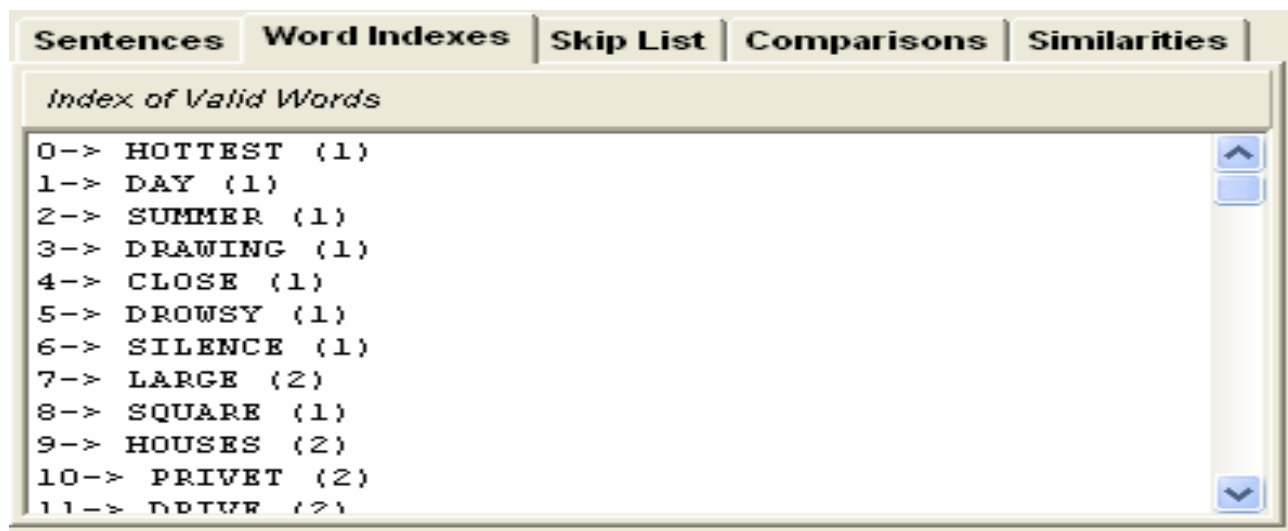

Gambar 5. Antarmuka sistem bagian process output terperinci pada tombol word indexes (kasus)

Pada bagian process output terperinci pada tombol skip list ini menampilkan daftar kata-kata yang bersifat umum (stop list) yang dimiliki oleh sistem (kasus), dapat dilihat seperti pada Gambar 6. 


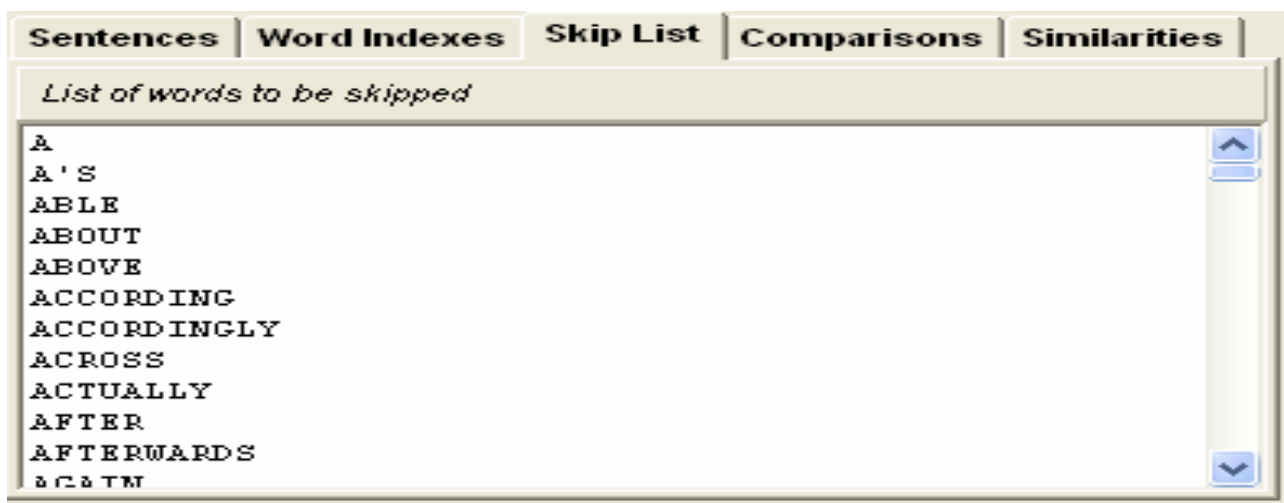

Gambar 6. Antarmuka sistem bagian process output terperinci pada tombol skip list (kasus)

Pada bagian process output terperinci pada tombol comparisons ini menampilkan nilai perbandingan antar blok (kasus), dapat dilihat seperti pada Gambar 7.

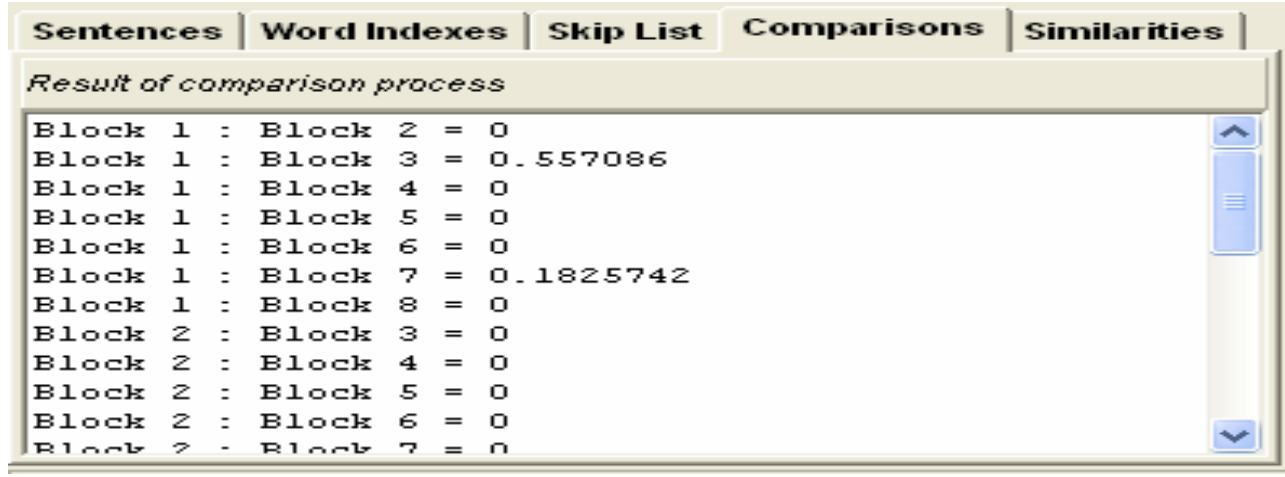

Gambar 7. Antarmuka sistem bagian process output terperinci pada tombol comparisons (kasus)

Pada bagian process output terperinci pada tombol similarities ini menampilkan nilai similarity coefficient tiap kalimat dalam dokumen, yang diperoleh dari penjumlahan nilai perbandingan keseluruhan blok (kasus), dapat dilihat seperti pada Gambar 8. 


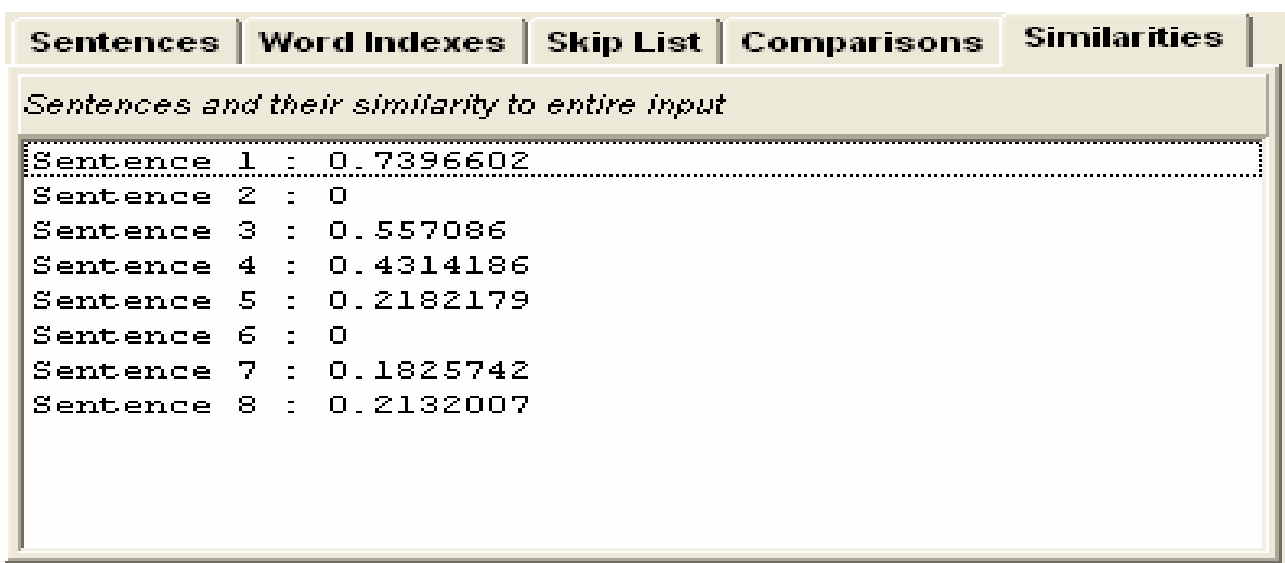

Gambar 8. Antarmuka sistem bagian process output terperinci pada tombol similarities (kasus)

Tabel 2. Kesesuaian penentuan pokok kalimat secara manual dan oleh sistem

\begin{tabular}{|c|c|c|c|c|}
\hline No. & Judul & Manual & Sistem & Sesuai \\
\hline 1. & Acacia & 1 & 1 & $\mathrm{Ya}$ \\
\hline 2. & AIDS & 1 & 5 & Tidak \\
\hline 3. & Architecture & 1 & 1 & $\mathrm{Ya}$ \\
\hline 4. & Bats & 14 & 12 & Tidak \\
\hline 5. & Black Hole & 1 & 1 & $\mathrm{Ya}$ \\
\hline 6. & Charles Ives & 1 & 4 & Tidak \\
\hline 7. & Communication & 2 & 5 & Tidak \\
\hline 8. & Elderhostel & 2 & 2 & $\mathrm{Ya}$ \\
\hline 9. & Federal Reserve System & 2 & 2 & $\mathrm{Ya}$ \\
\hline 10. & Fertilizer & 7 & 2 & Tidak \\
\hline 11. & First Horse & 1 & 4 & Tidak \\
\hline 12. & Fossil & 1 & 1 & Ya \\
\hline 13. & Harry & 1 & 1 & Ya \\
\hline 14. & Health Food & 6 & 6 & $\mathrm{Ya}$ \\
\hline 15. & Indian Caste & 4 & 2 & Tidak \\
\hline 16. & Influenza & 13 & 4 & Tidak \\
\hline 17. & Insects & 1 & 1 & $\mathrm{Ya}$ \\
\hline 18. & International Justice & 1 & 1 & $\mathrm{Ya}$ \\
\hline 19. & Massachusetts & 1 & 5 & Tidak \\
\hline 20. & Memory Trace & 1 & 1 & Ya \\
\hline 21. & Mountain & 1 & 6 & Tidak \\
\hline 22. & MUZAK & 1 & 1 & $\mathrm{Ya}$ \\
\hline 23. & Nobel & 5 & 5 & $\mathrm{Ya}$ \\
\hline 24. & Noise & 3 & 6 & Tidak \\
\hline 25. & Ocean & 1 & 5 & Tidak \\
\hline 26. & Opera & 3 & 3 & Ya \\
\hline 27. & Property & 2 & 4 & Tidak \\
\hline 28. & Relationship Social & 3 & 3 & $\mathrm{Ya}$ \\
\hline 29. & Simcity & 1 & 2 & Tidak \\
\hline 30. & Smallpox & 1 & 1 & Ya \\
\hline 31. & Sociology & 1 & 3 & Tidak \\
\hline 32. & The Protozoans & 1 & 3 & Ya \\
\hline
\end{tabular}

56 Erwin - Sistem Pengidentifikasi Otomatis Pokok Kalimat Suatu Paragraf dalam Dokumen... 


\section{PENUTUP DAN KESIMPULAN}

Perangkat lunak yang dibangun menggunakan kakas pemrograman Borland Delphi 6.0 baru merupakan intisari kasus permasalahan saja. Perangkat penentuan pokok kalimat secara otomatis dalam suatu paragraf akan dikembangkan lagi untuk dapat memprediksi topik dari seluruh pustaka yang ada. Hasil yang dicapai sudah cukup menggambarkan kesimpulan pokok kalimat yang diinginkan walaupun pada beberapa bagian masih terdapat ketidaksesuaian penentuan pokok kalimat antara secara manual dengan sistem. Kesimpulan yang didapat untuk penelitian selanjutnya adalah mengembangkannya untuk dapat menentukan topik dari suatu paragraf.

Dari pengujian yang telah dilakukan oleh sistem dapat diperoleh bahwa kesesuaian penentuan pokok kalimat yang dilakukan secara manual dan yang dilakukan oleh sistem dari 32 kali pengujian adalah sebesar 50\%, dapat dilihat pada Gambar 9.

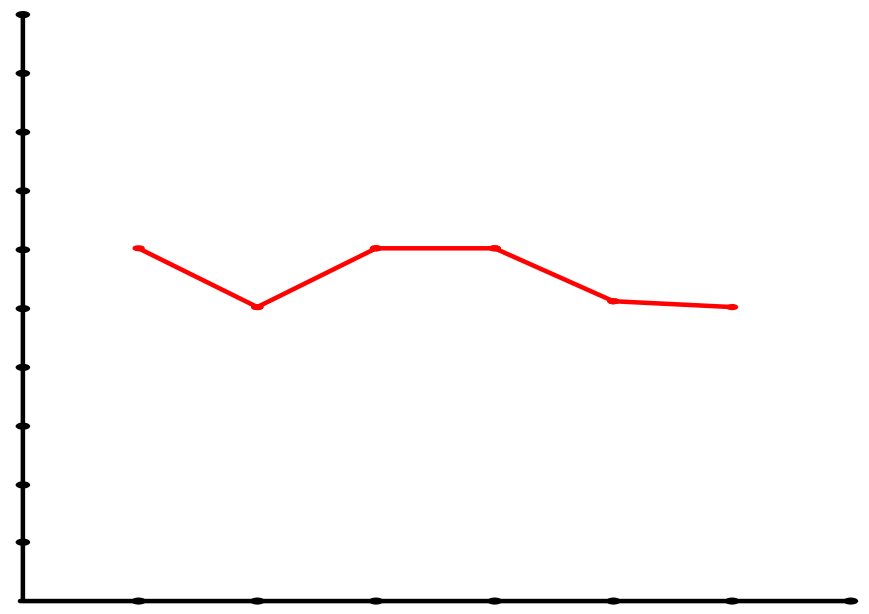

Gambar 9. Grafik kesesuaian penentuan pokok kalimat secara manual dengan sistem

\section{PUSTAKA}

Erwin, M. (2004). Relevance feedback pada sistem temu kembali informasi menggunakan algoritma genetika, Thesis Magister Informatika ITB, Bandung.

Frakes, W., dan Ricardo, B. Y. (1992). Information Retrieval Data Structure and Algorithms, Prentice Hall.

Grossman, D., dan Ophir, F. (1998). Information Retrieval: Algorithms and Heuristics, Kluwer Academic Publisher.

Hearst, M. A., dan Christian, P. (1993). Subtopic structuring for Full-Length Document Access, Proceedings of SIGIR, Pittsburgh. http://www.sims.Berkeley.edu/ hearst/publication.shtml.

Mandala, R., Takenobu, T., dan Hozumi, T. (1999). Query expansion using heterogenous thesauri. Proceeding of Information Processing and Management. 
Mandala, R., Takenobu, T., dan Hozumi, T. (2000). The exploration and Analysis of Using Multiple Thesaurus types for Query Expansion in Information Retrieval. Journal of Information Processing.

Mandala, R. (2002). Sistem Temu-kembali informasi dengan menggunakan model probabilistik, Jurnal Informatika, ITB, Bandung.

Setiawan, K. (2003). Paradigma Sistem Cerdas. BayuMedia Publishing, Malang: Jawa Timur.

\section{LAMPIRAN DOKUMEN PENGUJIAN}

\section{Dokumen 1. Acacia}

The Acacia, a genus of trees and shrubs of the mimosa family that originated in Australia, has long been used there in building simple mud and stick structures. The acacia is called a wattle in Australia, and the structures are said to be made of daub and wattle. The acacia is actually related to the family of plants known as legumes that includes peas, beans, lentils, peanuts, and pods with beanlike seeds. Some acacias actually produce edible crops. Other Acacia varieties are valued for the sticky resin, called gum arabic or gum acacia, used widely in medicines, foods, and perfumes, for the dark dense wood prized for making pianos, or for the bark, rich in tannin, a dark, acidic substance used to cure the hides of animals, transforming them into leather.

Pokok Kalimat:

The Acacia, a genus of trees and shrubs of the mimosa family that originated in Australia, has long been used there in building simple mud and stick structures

\section{Dokumen 5. Black Hole}

A black hole is a region of space created by the total gravitational collapse of matter. It is so intense that nothing, not even light or radiation, can escape. In other words, it is one way surface through which matter can fall inward but cannot emerge. Some astronomers believe that a black hole ney be formed when a large star collapses inward from its own weight. So long as they are emitting heat and light into space, stars support themselves against their own gravitational pull with the outward thermal pressure generated by heat from nuclear reactions deep in their interiors. But if a star eventually exhausts its nuclear fuel, then its unbalanced gravitational attraction could cause it to contract and collapse. Furthermore, it could begin to pull in surrounding matter, including nearby comets and planets, creating a black hole.

Pokok Kalimat:

A black hole is a region of space created by the total gravitational collapse of matter

\section{Dokumen 8. Eldherhostel}

One of the most succesfull educational programs for adults is the Elderhostel, designed for students over the age sixty. Initiated in 1975 by five 
colleges in New Hampshire, Elderhostel was originally a one-week summer program for senior citizens combining travel and college residence with enrichment courses. The concept has been so popular that it has grown rapidly to include a network of more than three hundred colleges and universities in all fifty states. Host institutions have expanded to include museums, parks, and other outdoor centers as well as traditional college campuses, and one, two, or threeweek programs are now available year round. Although courses are not offered for credit, and no exams are required, the classes are taught by highly qualified faculty at thehost college.

Pokok Kalimat:

Initiated in 1975 by five colleges in New Hampshire, Elderhostel was originally a one-week summer program for senior citizens combining travel and college residence with enrichment courses

\section{Dokumen 12. Fossil}

Fossils are the remains of organisms that have been preserved. Some of the most common fossils are shells, skeletons, leaves, and insects. they are occasionally preserved in ice, but most have been burried in mud or sand that collects at the bottom of bodies of water, especially lakes, seamps, and oceans. In order for fossil to form, the animals and plants must be buried quickly; otherwise, the organisms will disintegrate. If they are buried in loose sediment, the soft tissues will begin to decay. But the harder structures such as bones and shells will remain intact for much longer. After years of pressure from the layers of sediment above them, the lower layers of sediment turn into rock, encapsulating the organisms.

Pokok Kalimat:

Fossils are the remains of organisms that have been preserved

\section{Dokumen 17. Insects}

Insects, the most numerous creatures on our planet, are also the most adaptable. They require little food they are small. They easily find shelter and protection in small crevices in trees and surface geological formations. Species of insects can evolve quickly because of their rapid reproduction cycle; they live in every climate, some making their homes in the frozen Arctic regions and many others choosing the humid, warm, and nutrient-rich rain forest environment. An active part of the natural food cycle, insects provide nutrition for animals and devour waste products of other life forms.

Pokok Kalimat:

Insects, the most numerous creatures on our planet, are also the most adaptable. 